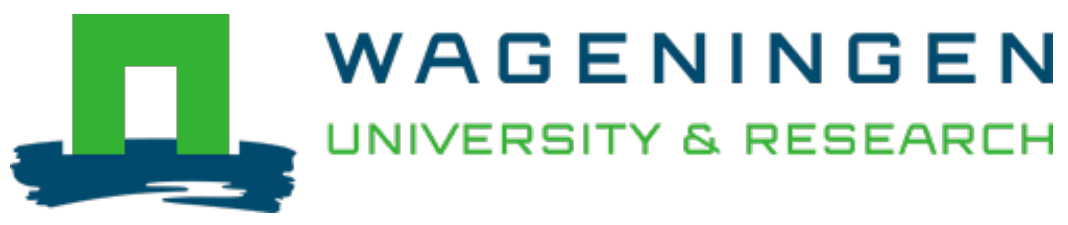

\title{
Effect of neutrase, alcalase, and papain hydrolysis of whey protein concentrates on iron uptake by Caco-2 cells
}

\author{
Journal of Agricultural and Food Chemistry \\ Ou, K.Q.; Liu, Y.Z.; Zhang, L.B.; Yang, X.G.; Huang, Z.W. et al \\ https://doi.org/10.1021/jf100055y
}

This publication is made publicly available in the institutional repository of Wageningen University and Research, under the terms of article $25 \mathrm{fa}$ of the Dutch Copyright Act, also known as the Amendment Taverne. This has been done with explicit consent by the author.

Article 25 fa states that the author of a short scientific work funded either wholly or partially by Dutch public funds is entitled to make that work publicly available for no consideration following a reasonable period of time after the work was first published, provided that clear reference is made to the source of the first publication of the work.

This publication is distributed under The Association of Universities in the Netherlands (VSNU) 'Article $25 \mathrm{fa}$ implementation' project. In this project research outputs of researchers employed by Dutch Universities that comply with the legal requirements of Article $25 \mathrm{fa}$ of the Dutch Copyright Act are distributed online and free of cost or other barriers in institutional repositories. Research outputs are distributed six months after their first online publication in the original published version and with proper attribution to the source of the original publication.

You are permitted to download and use the publication for personal purposes. All rights remain with the author(s) and / or copyright owner(s) of this work. Any use of the publication or parts of it other than authorised under article $25 \mathrm{fa}$ of the Dutch Copyright act is prohibited. Wageningen University \& Research and the author(s) of this publication shall not be held responsible or liable for any damages resulting from your (re)use of this publication.

For questions regarding the public availability of this publication please contact openscience.library@wur.nl 


\title{
Effect of Neutrase, Alcalase, and Papain Hydrolysis of Whey Protein Concentrates on Iron Uptake by Caco-2 Cells
}

\author{
Keqin Ou, ${ }^{\dagger}$ Yunzhu Liu, ${ }^{\dagger}$ Liebing Zhang, ${ }^{\dagger}$ Xiaoguang Yang, ${ }^{*}$ Zhenwu Huang, ${ }^{\star}$ \\ M. J. Robert Nout, ${ }^{\S}$ AND JiAnFEn LianG ${ }^{*}, \dagger$ \\ ${ }^{\dagger}$ College of Food Science and Nutritional Engineering, China Agricultural University, Beijing 100083, \\ People's Republic of China, Key Laboratory of Trace Element Nutrition, Ministry of Health (MOH), \\ Institute of Nutrition and Food Safety, Chinese Centre for Disease Control and Prevention, Beijing \\ 100050, People’s Republic of China, and ${ }^{\S}$ Laboratory of Food Microbiology, Wageningen University, \\ Wageningen, The Netherlands
}

\begin{abstract}
Effects of enzymatic hydrolysates of whey protein concentrates (WPC) on iron absorption were studied using in vitro digestion combined with Caco-2 cell models for improved iron absorption. Neutrase- and papain-treated WPC could improve iron absorption; especially hydrolysates by Neutrase could significantly increase iron absorption to $12.8 \%$ compared to $3.8 \%$ in the control. Hydrolysates by alcalase had negative effects to the lowest at $0.57 \%$. Two new bands at molecular weights (MW) around and below $10 \mathrm{kDa}$ occurred at tricine-SDS-PAGE of hydrolysates by Neutrase, and one new band at MW below $10 \mathrm{kDa}$ occurred in hydrolysates by papain. No new band was observed in hydrolysates by alcalase. Concentration of free amino acids indicated that, except for tyrosine and phenylalanine, amino acids in papain-treated hydrolysates were higher than that of alcalase, and no cysteine and proline were found in hydrolysates by alcalase. The results suggested that hydrolysate by Neutrase-treated WPC is a promising facilitator for iron absorption. Peptides of MW around and lower than $10 \mathrm{kDa}$ and aspartic acid, serine, glutamic acid, glycin, cysteine, histidine, and proline may be contributors to enhancement.
\end{abstract}

KEYWORDS: Iron absorption; enzymatic hydrolysates; in vitro digestion; Caco-2 cells

\section{INTRODUCTION}

Iron is one of the essential trace elements for human nutrition, and the only way to obtain it is through dietary intake. Iron deficiency is prevalent, caused by either insufficient intake or the presence of iron absorption inhibitors. In our previous studies, we have tried different ways to decrease contents of phytic acid, which is mentioned as an important inhibitor of iron absorption, in rice for improved bioavailability of minerals. However, the efficacy of those approaches is limited $(1,2)$. Dietary iron fortification or supplementation is another way to improve iron nutrition. The low bioavailability and poor taste of common supplementary substances hindered their application. In recent years, new supplements with relatively higher bioavailability and better taste, such as ferrous ethylenediaminetetraacetic acid (FeEDTA), ferrous glycinate, and lactoferrin have been developed. However, these new sources are not popular because of economic aspects (3).

It was also reported that the presence of some ingredients, such as ascorbic acid and some amino acids, could improve the bioavailability of iron. Enhancement of protein, peptides, and amino acids in the bioavailability and absorption of iron is one of

\footnotetext{
*Address correspondence to this author at the China Agricultural University (East Campus), P.O. Box 294, Beijing 100083, People's Republic of China (telephone +86-10-62737699; fax +86 1062737699 ; e-mail liangjf@cau.edu.cn).
}

the most interesting research fields. It was reported that some proteins, such as egg yolk protein and casein, inhibited the bioavailability of iron, which was caused by the formation of an insoluble iron-protein complex or the presence of competing minerals [e.g., calcium in casein (4-7)]. Proteins and peptides, mainly from milk and meat, enhancing iron absorption were also reported $(8-10)$. It was summarized that these enhancers had similar characteristics: (1) the presence of some "specific" amino acids, such as Pro, Phe, Met, His, Ser, Glu, Asp, and Cys, although conclusions of different studyies were not in agreement and the exact effect and mechanism are as yet uncertain $(10,11)$; (2) the presence of sulfhydryl $(-\mathrm{SH})$ groups, which led to the assumption that $-\mathrm{SH}$ could reduce $\mathrm{Fe}^{3+}$ to the more soluble $\mathrm{Fe}^{2+}$ (12); (3) low molecular weight (MW), most of the enhancers having MW lower than $10 \mathrm{kDa}(5,10,13,14)$.

Studies on protein showed that alcalase and Flavourzyme have extensive proteolytic activity for low MW peptides and amino acids $(13-15)$. However, the effect and application of these hydrolysates on fortification of minerals is scare. To achieve improved absorption of fortified iron, whey protein concentrate (WPC), which is a byproduct of cheesemaking and casein manufacture in the dairy industry, growing as the same rate as milk ( $>2 \%$ per year) (16), was selected as raw material for hydrolysates containing peptides and different compositions of amino acids. The objectives of this study were (1) to evaluate the possibility of application of enzymatically treated WPC for 
improvement of iron absorption using in vitro digestion combined with Caco- 2 cell models and (2) to analyze the mechanisms of WPC hydrolysates on iron absorption.

\section{MATERIALS AND METHODS}

Preparation of WPC Hydrolysates. The 5\% WPC solution was kept in an incubator at $85^{\circ} \mathrm{C}$ for $15 \mathrm{~min}$. After the solution had cooled to $50{ }^{\circ} \mathrm{C}$, the $\mathrm{pH}$ was adjusted to 5.5, 7.0, and 8.0, respectively, for papain, Neutrase, and alcalase using $1 \mathrm{M} \mathrm{NaOH}$ or $1 \mathrm{M} \mathrm{HCl}$, and these values were maintained during enzymatic treatment. The ratio of enzyme to substrate was $3000 \mathrm{U} \mathrm{g}^{-1}$ on a protein basis. WPC solution was kept at $50{ }^{\circ} \mathrm{C}$ for Neutrase and alcalase and at $54^{\circ} \mathrm{C}$ for papain. During enzymatic treatment, samples were collected at intervals of every 30 min until $4-5 \mathrm{~h}$. Enzymes were inactivated by heating the reaction mixture for $10 \mathrm{~min}$ at $100^{\circ} \mathrm{C}$. The hydrolysate solutions were either lyophilized for further in vitro digestion or centrifuged at $4800 \mathrm{~g}$ for $15 \mathrm{~min}$, and the supernatants were taken for subsequent determination of degree of hydrolysis (DH). The DH was determined following the procedures used by Adler-Nissen, which is basically a spectrophotometric assay of the chromophore formed by the reaction of trinitrobenzenesulfonic acid (TNBS) with primary amines (17).

In Vitro Digestion of WPC Hydrolysates. The in vitro digestion procedure described by Kiers et al. (18) was applied with slight modification. About $1 \mathrm{~g}$ (accuracy $0.0001 \mathrm{~g}$ ) of WPC hydrolysate was dissovled in deionized water and fortified with iron in the form of $\mathrm{FeSO}_{4}$ according to the Chinese Hygienic Standard (GB14880-94). Solutions were then digested with pepsin and pancreatin to simulate the digestion system of the human body. The digests were subjected to centrifugation at $5000 \mathrm{~g}$ for 25 min at $4{ }^{\circ} \mathrm{C}$, and the supernatants were filtered through a membrane with a pore diameter of $0.22 \mu \mathrm{m}$ for iron uptake experiments. In vitro digestion was carried out in triplicate.

Iron Uptake by Caco-2 Cells. Caco-2 cells originating from human colorectal carcinoma were obtained from the American Type Culture Collection (ATCC, Rockville, MD) at passage around 30-50 and used in experiments within 5 passages. Cells were seeded at a level of $(1-1.5) \times$ $10^{5}$ cells $/ \mathrm{cm}^{2}$ in 12-well transwell plates (Corning Inc.) and maintained under conditions described by Glahn et al. (19). The iron uptake experiment was conducted when the activity of alkaline phosphatase could be detected and the transmonolayer electrical resistance was $>500 \Omega \mathrm{cm}^{-2}$. The protocols used in the iron uptake followed those of Glahn et al. (20). Briefly, growth medium was removed from the transwell by aspiration, and the upper and lower chambers were rinsed with phosphate-buffered saline (PBS). Then $1.5 \mathrm{~mL}$ of Hanks' balanced salt solution (pH 7.2-7.4) was filled in the lower chamber, whereas $0.5 \mathrm{~mL}$ in vitro digest was added to the upper chamber. Transport time was $1 \mathrm{~h}$ at $37^{\circ} \mathrm{C}$. Iron uptake was terminated by collecting the upper and lower chamber solutions separately and rinsing the upper chamber with 3 volumes $(0.5 \mathrm{~mL})$ of stop solution [140 mM NaCl, $10 \mathrm{mM}$ PIPES [piperazine- $N, N^{\prime}$-bis(2-ethanesulfonic acid)], $\mathrm{pH} 6.8,4{ }^{\circ} \mathrm{C}$ ]. Next, $0.5 \mathrm{~mL}$ of removal solution (stop solution with $5 \mathrm{mM}$ bathophenanthroline disulfonic acid and $5 \mathrm{mM}$ sodium dithionite, $\mathrm{pH} 6.8,4{ }^{\circ} \mathrm{C}$ ) was used to remove the nonspecifically bound iron. Then, each monolayer received an additional 2 volumes $(0.5 \mathrm{~mL})$ of stop solution. The outside of each insert was washed with $1.0 \mathrm{~mL}$ of stop solution $\left(\mathrm{pH} 6.8,4^{\circ} \mathrm{C}\right)$. This rinse solution was added to the lower chamber. After collection of all solutions, cells were lysed and harvested by adding 2 volumes $(0.5 \mathrm{~mL})$ of $1 \mathrm{M} \mathrm{NaOH}$ to each insert (21). The experiment was carried out at least in quadruplicate.

Determination of Iron Contents and Bioavailability. Iron contents in WPC, hydrolysate solutions, and dialysates and Caco-2 cell absorption were measured by inductively coupled plasma atomic emission spectrometry (ICP-AES) after microwave-accelerated digestion in triplicate, and the averages were used to calculate the bioavailability and dialyzability of iron, which were defined as

$$
\begin{gathered}
\text { iron bioavailability }(\%)=\frac{\text { iron }_{(\text {transport }+ \text { retained })}}{\text { total iron }} \times 100 \% \\
\quad \text { iron dialyzability }(\%)=\frac{\text { dialyzable iron }}{\text { total iron }} \times 100 \%
\end{gathered}
$$

where iron $_{\text {(transport+retained) }}$ refers to the content of iron transported into the lower chamber solution plus that retained in the cells. Dialyzable iron is the iron that could pass through the membrane $(0.22 \mu \mathrm{m})$ after in vitro digestion. Total iron is the total content of iron in the enzymatic hydrolysates after fortification.

Tricine-Sodium Dodecyl Sulfate-Polyacrylamide Gel Electrophoresis (SDS-PAGE). Tricine-SDS-PAGE analysis of peptides was performed with the methods described by Schagger and Von Jagow (22). The composition of acrylamide solutions and of all gels is defined by the letters T and C. Briefly, the gel was composed of a small-pore gel $(16.5 \% \mathrm{~T})$ overlaid by a $10 \% \mathrm{~T}, 3 \% \mathrm{C}$ spacer gel that again was overlaid by a $4 \% \mathrm{~T}$, $3 \% \mathrm{C}$ stacking gel. The anode buffer was $0.2 \mathrm{M}$ Tris- $\mathrm{HCl}, \mathrm{pH} 8.9$, and the cathode buffer was $0.1 \mathrm{M}$ Tris-HCl, $\mathrm{pH} 8.25,0.1 \mathrm{M}$ tricine, and $0.1 \%$ SDS. The electrophoresis runs started at $30 \mathrm{~V}$ and changed to $100 \mathrm{~V}$ after about $1.5 \mathrm{~h}$, when the sample had completely entered the stacking gel.

Analysis of Free Amino Acids. The samples were deproteinized with $15 \%$ trichloroacetic acid (TCA) and centrifuged at $5000 \mathrm{~g}$ for $20 \mathrm{~min}$, and then the supernatant was filtered through a pore diameter $0.45 \mu \mathrm{m}$ membrane prior to the amino acid determination carried out on an amino acid analyzer (Hitachi L-8800, Japan).

All glassware in this study was steeped in $30 \% \mathrm{HNO}_{3}$ overnight and then rinsed with deionized water before use to avoid mineral contamination.

Statistical Analysis. All measurements were expressed as means \pm SD. The data were analyzed by SPSS 10.0 one-way analysis of variance (ANOVA). A multiple-comparison procedure of the treatment means was performed by Duncan's new multiple-range test.

\section{RESULTS}

Effects of Enzymatically Treated WPC on Fortified Iron Absorption by Caco-2 Cells. The enzymes and treatment periods applied significantly affected the effects of hydrolysates on bioavailability of fortified iron by Caco-2 cells $(p<0.01)$, as shown in Figure 1.

Effect of Neutrase. Compared to control (nontreated WPC), Neutrase-treated WPC significantly improved iron uptake by Caco- 2 cells. The highest iron bioavailability occurred at hydrolysates obtained after $1 \mathrm{~h}$ of treatment, which was $12.8 \%$, about 4 -fold the control $(3.4 \%)$. The lowest $(5.8 \%)$ was at $5 \mathrm{~h}$ of treatment. Iron absorptions with hydrolysates obtained after $1-4 \mathrm{~h}$ treatments were significantly higher than that of control $(p<0.05)$, and no statistical differences were observed among hydrolysates treated for 2-4 h.

Effect of Papain. Depending on the treatment period, papaintreated WPC exhibited improved or inhibitory effects on iron uptake by Caco-2 cells. Compared to control, WPC treated with papain for $3-5 \mathrm{~h}$ improved absorption of iron, whereas treatment for $1-2 \mathrm{~h}$ inhibited iron absorption significantly $(p<0.05)$. With prolonged period from 1 to $5 \mathrm{~h}$, WPC treated with papain increased iron absorption and reached a relatively stable level (8\%) after $3 \mathrm{~h}$. No significant difference was observed among 3, 4, and $5 \mathrm{~h}$.

Effect of Alcalase. Different from Neutrase and papain, alcalase-treated WPC had a negative effect on iron absorption. Except for treatments for 1 and $2 \mathrm{~h}$, which were at a comparable level with the control, hydrolysates from other periods decreased iron absorption, and hydrolysates from $3 \mathrm{~h}$ significantly lowered the iron absorption to $0.57 \%(p<0.05)$.

In vitro dialyzability of iron affected by WPC treated with Neutrase, papain, and alcalase for different periods is shown in Table 1. Dialyzability of iron was very close to $100 \%$ for WPC hydrolysates by Neutrase and alcalase, and no significant differences were observed among treatment periods for both enzymes. However, papain hydrolysates significantly inhibited the amount of soluble iron $(p<0.01)$, which was in the range of $21.3-28.6 \%$.

Effect of Hydrolysis on Composition of WPC. DH of WPC. Mean DH $( \pm \mathrm{SD})$ of WPC by proteases is shown in Figure 2. In our study design, we controlled the DH of WPC in the range of $0-30 \%$. In intervals of $0.5-1 \mathrm{~h}, \mathrm{DH}$ by papain was significantly higher than that of alcalase $(p<0.01)$. However, at intervals of 


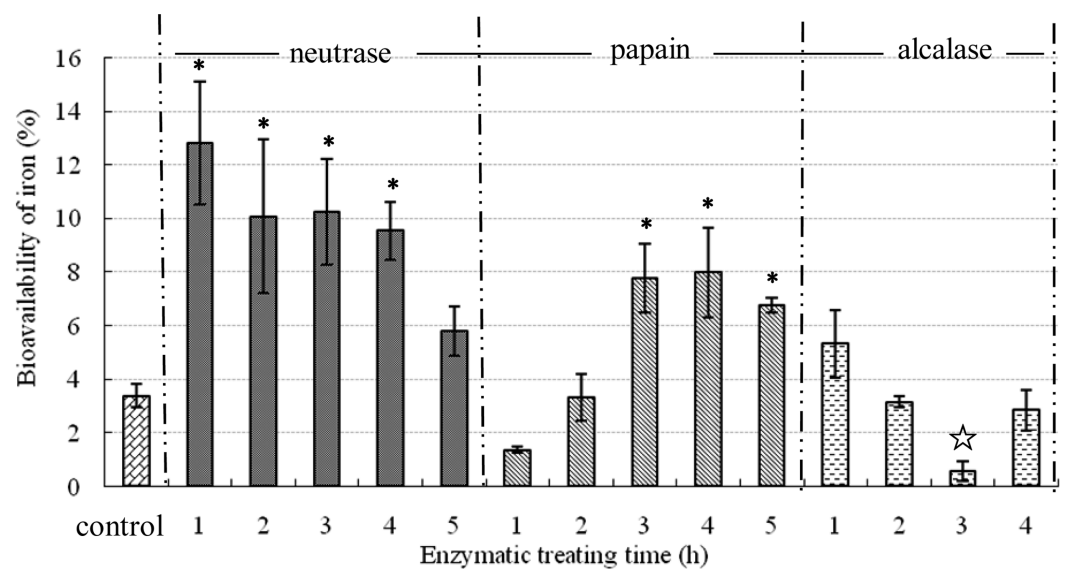

Figure 1. Bioavailability of iron with WPC hydrolysates treated with Neutrase, papain, and alcalase. *, significantly increased iron absorption (to control, $p<0.01$ ); $\downarrow$, significantly decreased iron absorption (to control, $p<0.01$ ). The experiment of iron uptake was carried out at least in quadruplicate.

Table 1. Dialyzability (Percent) of Iron Affected by WPC Treated with Neutrase, Papain, and Alcalase for Different Periods ${ }^{a}$

\begin{tabular}{cccc}
\hline treatment time $(\mathrm{h})$ & Neutrase & papain & alcalase \\
\hline 1 & $93.52 \pm 5.81 \mathrm{a}$ & $24.27 \pm 6.28 \mathrm{a}$ & $103.75 \pm 35.09 \mathrm{a}$ \\
2 & $90.15 \pm 8.61 \mathrm{a}$ & $28.62 \pm 4.74 \mathrm{~b}$ & $112.68 \pm 2.05 \mathrm{a}$ \\
3 & $103.71 \pm 5.20 \mathrm{a}$ & $24.03 \pm 1.50 \mathrm{a}$ & $93.83 \pm 14.10 \mathrm{a}$ \\
4 & $107.44 \pm 18.87 \mathrm{a}$ & $28.51 \pm 2.31 \mathrm{~b}$ & $83.97 \pm 7.62 \mathrm{a}$ \\
5 & $90.35 \pm 6.35 \mathrm{a}$ & $21.35 \pm 1.67 \mathrm{a}$ &
\end{tabular}

${ }^{a}$ The experiment of iron dialysis was carried out in triplicate for each sample. Significance level is $p<0.05$.

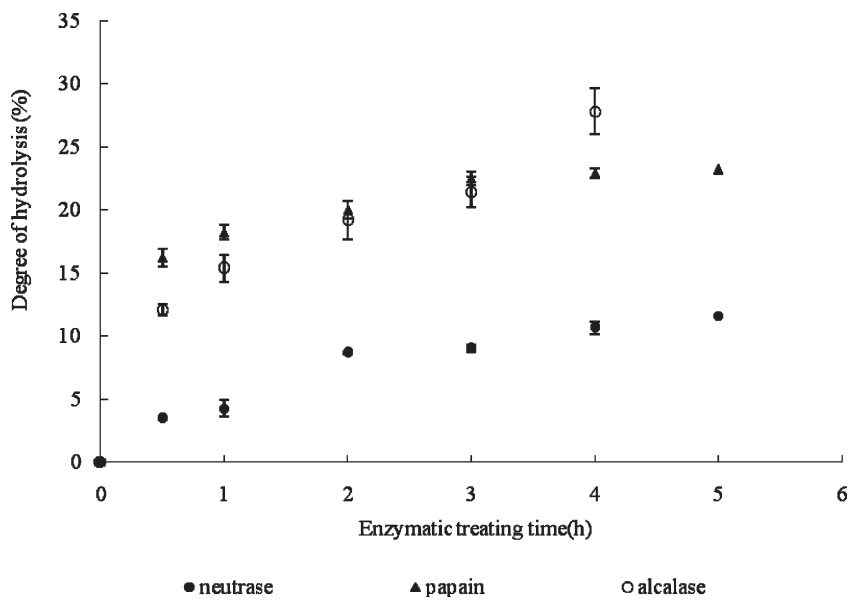

Figure 2. Degree of hydrolysis $( \pm S D)$ of whey protein concentrates by different enzymes: Neutrase $(\mathbf{O})$; papain $(\mathbf{\Delta})$, alcalase $(\bigcirc)$. The experiment of WPC hydrolysis was carried out in triplicate.

2 and $3 \mathrm{~h}$, they were at the same level $(p>0.05)$. At the same treatment intervals, $\mathrm{DH}$ by papain was $2.5-4.5$ fold that of Neutrase. With regard to $\mathrm{DH}$ by enzymes, it was increasingly ordered as papain $>$ alcalase $>$ Neutrase in the first $3 \mathrm{~h}$. However, alcalase had the highest DH after $4 \mathrm{~h}$ of treatment.

Tricine-SDS-PAGE. The electrophoretic patterns of Neutrase, papain, and alcalase WPC hydrolysates at each incubation time are shown in Figures 3-5. Compared to raw WPC, two new bands were observed at MW around and below $10 \mathrm{kDa}$ in hydrolysates by Neutrase, and main components such as BSA, $\mathrm{IgG}, \beta$-Lg, and $\alpha$-La were degraded to different extents. The band around $10 \mathrm{kDa}$ became lighter with treatment time. Different from the pattern of hydrolysates by Neutrase, Figures $\mathbf{4}$ and $\mathbf{5}$ illustrate a complete removal of BSA, IgG, $\beta$ - $\mathrm{Lg}$, and $\alpha$-La in all papain and alcalase hydrolysates of WPC at each time of incubation. Papain hydrolysates showed dispersion lower than $10 \mathrm{kDa}$, whereas neither band nor dispersion was observed for alcalase hydrolysates in this area.

Free Amino Acids. The free amino acid compositions of WPC hydrolysates by Neutrase, papain, and alcalase at each time of enzymatic incubation are listed in Table 2 . With the prolonged enzymatic treatment time, the contents of most amino acids for each hydrolysate increased. In general, the content of amino acids in papain WPC hydrolysates was the highest. Compared to papain and alcalase, except for Tyr and Phe, higher contents of the other 15 types of amino acids were detected for papain than alcalase at each incubation time. No Cys and Pro were found in hydrolysates by alcalase and no Cys, Leu, His, and Pro by Neutrase.

Table 3 presents the free amino acid composition of WPC hydrolysate by Neutrase, papain, and alcalase after in vitro digestion. The contents of each free amino acid increased at corresponding time when compared with Table 2. Digests from papain hydrolysates showed higher contents of Asp, Ser, Glu, Gly, Cys, His, and Pro than alcalase.

\section{DISCUSSION}

The most important finding in the present study is that WPC hydrolysates by protease affect absorption of iron by Caco- 2 cells differently. Hydrolysates by Neutrase strikingly increased the fortified iron absorption. Proteins of WPC could be degraded into peptides and/or amino acids when treated with proteolytic enzymes. With enzymatic degradation, occurrence of decreased MW, increased charge, exposure of hydrophobic groups, and disclosure of reactive amino acid side chains will happen, which may result in changes of physiological and nutritional properties.

Iron dialyzability is a primary step before iron can be absorbed in the small intestine (23). When evaluated with in vitro digestion system, the dialyzabilities of fortified iron from WPC hydrolysates incubated with alcalase and Neutrase reached almost $100 \%$, which is well in accordance with Kim's report about alcalase hydrolysates (DH 13.60\%) led iron solubility at 97.6\%. However, dialyzability of iron with papain hydrolysates was $<30 \%$, which was significantly lower than hydrolysates by Neutrase and alcalase; more than two-thirds of fortified iron with papaintreated hydrolysates could not penetrate the dialysis membrane. This indicated that the binding of iron to papain-treated hydrolysates rendered iron insoluble or that the complex between iron and protein and/or peptides was too large to pass into the membrane (24). We are surprised to find there was no significant 


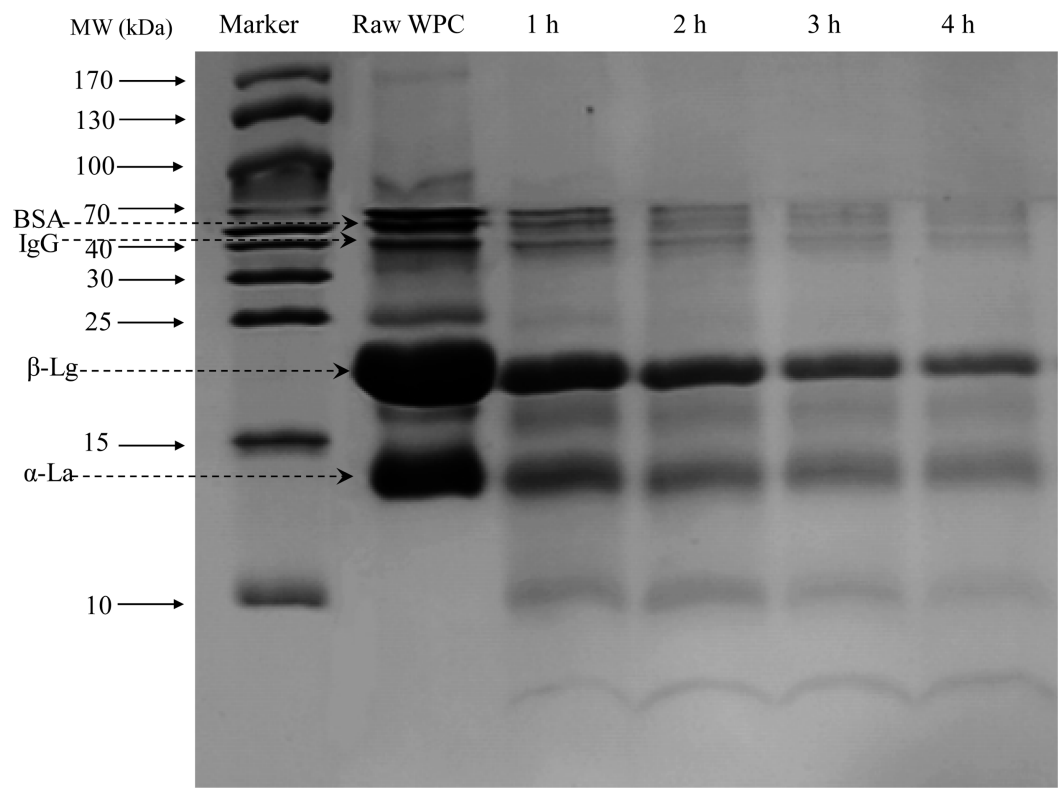

Figure 3. Tricine-SDS-PAGE of WPC hydrolysates by Neutrase.

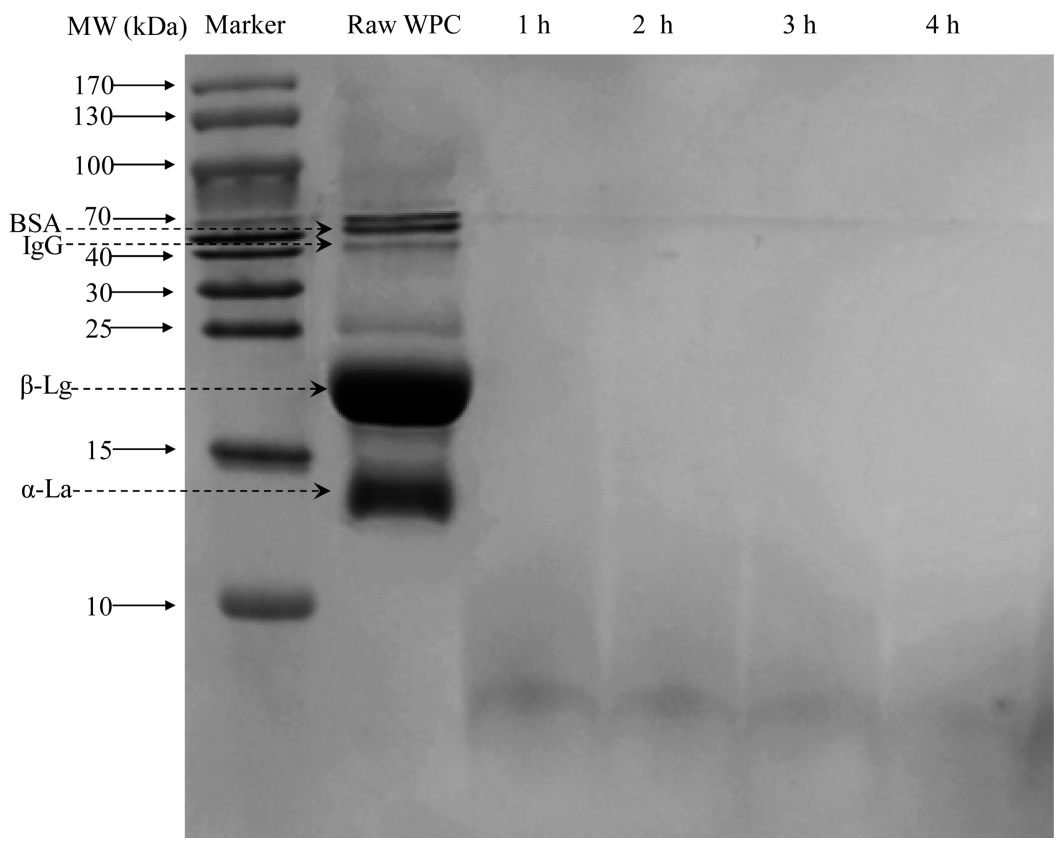

Figure 4. Tricine-SDS-PAGE of WPC hydrolysates by papain.

correlation between dialyzability and bioavailability of iron, conflicting with previous work that dialyzability is a predictive indicator of iron absorption (25). This suggested that the affinity of a compound for iron and the type of complex formed may be equally important in the determination of the effect on nonheme iron absorption. Therefore, the affinity of undigested or partially digested proteins for iron and the size of the compounds formed could determine the dialyzability of iron (24). These findings on bioavailability and dialyzability of iron further encouraged the investigation of characteristics of these WPC hydrolysates.

To reveal the mechanisms of WPC hydrolysates on iron bioavailability, $\mathrm{DH}$ of hydrolysates, gel electrophoresis, and composition of amino acids of raw and in vitro digested WPC hydrolysates were analyzed. For three enzymes, DH of WPC increased with time and trends of DH were not similar to trends of iron bioavailability. Iron absorption was improved (to control) at the starting period of hydrolysis, and the decreased as $\mathrm{DH}$ increased by Neutrase could be explained by production of some iron-binding peptides, which could bind minerals through carboxyl oxygens in the peptide chain (26); however, these peptides may subsequently be degraded as the hydrolysis continued and thus result in progressively lower bioavailability of iron at higher DH. On the other hand, changes of composition of amino acids may be related to increase of iron bioavailability during hydrolysis. In agreement with previous work, more extensive hydrolysis of WPC was observed by alcalase than by Neutrase (26), which may contribute considerable capacity of alcalase on breakage of large numbers of peptide bonds. A relatively crude alcalase, which was an extraction of Bacillus licheniformis, contains several proteases with different specificities (27). Similar DH of WPC by alcalase did not show certain levels of iron absorption as Neutrase or papain. For alcalase-treated hydrolysates, iron 


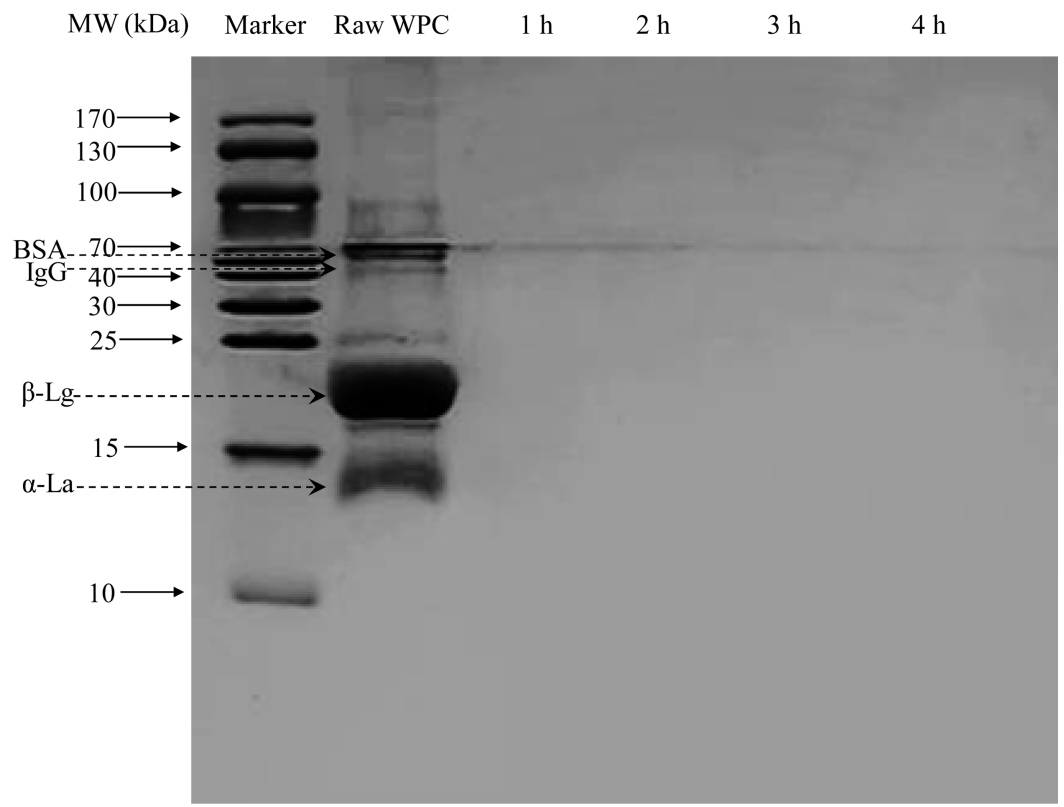

Figure 5. Tricine-SDS-PAGE of WPC hydrolysates by alcalase.

Table 2. Contents of Free Amino Acids in Enzymatic Hydrolysates (Milligrams per $100 \mathrm{~g}$, Dry Basis)

\begin{tabular}{|c|c|c|c|c|c|c|c|c|c|c|c|c|}
\hline & & $1 \mathrm{~h}$ & & & $2 \mathrm{~h}$ & & & $3 \mathrm{~h}$ & & & $4 \mathrm{~h}$ & \\
\hline & Neutrase & papain & alcalase & Neutrase & papain & alcalase & Neutrase & papain & alcalase & Neutrase & papain & alcalase \\
\hline Asp & 10.2 & 413.8 & 1.0 & 11.7 & 387.9 & 1.9 & 12.2 & 379.3 & 2.3 & 13.9 & 440.4 & 4.0 \\
\hline Thr & 7.1 & 75.2 & 0.0 & 8.2 & 76.2 & 62.6 & 7.0 & 80.2 & 64.3 & 8.3 & 180.8 & 84.8 \\
\hline Ser & 1.3 & 194.8 & 65.8 & 1.6 & 200.3 & 59.1 & 1.5 & 207.3 & 67.3 & 2.2 & 259.6 & 81.5 \\
\hline Glu & 3.6 & 94.8 & 32.6 & 4.5 & 93.9 & 76.5 & 4.7 & 103.5 & 114.3 & 5.7 & 117.8 & 177.8 \\
\hline Gly & 5.8 & 366.6 & 0.0 & 8.2 & 302.2 & 0.0 & 8.3 & 404.6 & 2.0 & 9.8 & 359.4 & 2.7 \\
\hline Ala & 0.9 & 69.1 & 63.4 & 0.7 & 76.3 & 134.2 & 0.0 & 76.3 & 148.6 & 0.9 & 100.4 & 181.1 \\
\hline Cys & 0.0 & 195.5 & 0.0 & 0.0 & 187.7 & 0.0 & 0.0 & 188.2 & 0.0 & 0.0 & 162.1 & 0.0 \\
\hline Val & 23.9 & 68.7 & 15.3 & 25.5 & 59.2 & 21.4 & 23.2 & 70.6 & 27.1 & 28.2 & 81.0 & 40.0 \\
\hline Met & 9.4 & 67.1 & 0.0 & 12.0 & 71.9 & 2.7 & 11.0 & 73.0 & 5.0 & 13.8 & 92.8 & 9.0 \\
\hline Ile & 22.1 & 45.7 & 0.0 & 32.5 & 42.7 & 0.0 & 34.1 & 43.0 & 4.2 & 38.0 & 48.7 & 9.0 \\
\hline Leu & 0.0 & 448.8 & 66.1 & 0.0 & 480.7 & 128.3 & 0.0 & 490.7 & 190.9 & 0.0 & 607.9 & 292.8 \\
\hline Tyr & 183.0 & 268.1 & 299.9 & 195.6 & 209.3 & 360.9 & 172.0 & 257.1 & 417.1 & 194.2 & 234.0 & 510.5 \\
\hline Phe & 36.3 & 125.9 & 498.4 & 60.2 & 137.6 & 609.0 & 53.9 & 145.7 & 662.6 & 67.2 & 176.0 & 816.5 \\
\hline Lys & 6.9 & 190.1 & 4.4 & 7.7 & 207.8 & 7.9 & 8.2 & 215.2 & 11.5 & 9.5 & 275.9 & 24.7 \\
\hline His & 0.0 & 48.2 & 2.4 & 0.0 & 49.9 & 3.7 & 0.0 & 51.8 & 4.7 & 0.0 & 64.1 & 7.4 \\
\hline Arg & 20.5 & 143.4 & 6.8 & 34.5 & 149.4 & 11.3 & 30.1 & 152.5 & 15.4 & 36.1 & 190.8 & 21.8 \\
\hline Pro & 0.0 & 4.3 & 0.0 & 0.0 & 4.0 & 0.0 & 0.0 & 4.0 & 0.0 & 0.0 & 5.0 & 0.0 \\
\hline
\end{tabular}

absorption was $<20 \%$ of the control when DH was at $21.4 \%$. Our results disagreed with the results of bovine milk protein on iron absorption in human, which was that a higher DH of whey protein $(36 \%)$ led to a higher iron absorption than a lower one $(16 \%)$. This may be due to discrepancy of proteases, which resulted in different binding iron cations. Differences of iron absorption between hydrolysates by Neutrase, papain, and alcalase signified the importance of active sites on protein of enzymes and the DH because they markedly affect the composition of hydroysates, which may determine iron-binding capacity. Of them, the active sites of enzymes seem to be more important.

Results of electrophoretic patterns of WPC hydrolysates (Figures 3-5) give us another point. Figure 3 indicated a few remaining traces of $\mathrm{BSA}, \mathrm{IgG}, \beta$ - $\mathrm{Lg}$, and $\alpha$-La even after $5 \mathrm{~h}$ of incubation by Neutrase, whereas Figures $\mathbf{4}$ and $\mathbf{5}$ reveal complete removal of the major bands of whey protein by papain and alcalase. These results were well in correlation with the result of $\mathrm{DH}$, suggesting that the hydrolysis capability of Neutrase is weaker than that of papain and alcalase. Compared with hydrolysates by alcalase, the patterns of Neutrase-treated hydrolysates showed generation of new bands at MW of and lower than $10 \mathrm{kDa}$, whereas hydrolysates by papain had dispersion in the area of MW at $10 \mathrm{kDa}$. For Neutrase-treated hydrolysates, a more distinct band around $10 \mathrm{kDa}$ was exhibited. The generation of small molecular weight peptides $(<10 \mathrm{kDa})$ may be responsible for enhancing the effect on iron absorption. Our results supported the results that filtrates (MW $<10 \mathrm{kDa}$ ) of cow's milk whey obtained after ultrafiltration with a $10 \mathrm{kDa}$ membrane caused markedly greater Caco-2 cell ferritin formation than retentate (components $>10 \mathrm{kDa})(5)$. Study on human milk also showed that low molecular weight components, which may include carbohydrates, salts, peptides, and vitamins, enhance iron uptake (5).

Although except for the dispersion area of MW lower than $10 \mathrm{kDa}$ occurring in papain WPC hydrolysates, a high similarity was observed in the electrophoretic patterns for papain and alcalase WPC hydrolysates, and distinctions were found in the composition of amino acids, either before or after in vitro digestion. Higher contents of Asp, Ser, Glu, Gly, Cys, His, and Pro in papain hydrolysates may be also the reason for its 
Table 3. Contents of Free Amino Acids in Enzymatic Hydrolysates after in Vitro Digestion (Milligrams per $100 \mathrm{~g}$, Dry Basis)

\begin{tabular}{|c|c|c|c|c|c|c|c|c|c|c|c|c|}
\hline & \multicolumn{3}{|c|}{$1 \mathrm{~h}$} & \multicolumn{3}{|c|}{$2 \mathrm{~h}$} & \multicolumn{3}{|c|}{$3 \mathrm{~h}$} & \multicolumn{3}{|c|}{$4 \mathrm{~h}$} \\
\hline & Neutrase & papain & alcalase & Neutrase & papain & alcalase & Neutrase & papain & alcalase & Neutrase & papain & alcalase \\
\hline Asp & 187.1 & 427.6 & 70.0 & 174.6 & 371.3 & 64.0 & 197.1 & 554.4 & 64.5 & 192.0 & 464.4 & 58.3 \\
\hline Thr & 490.2 & 612.0 & 644.9 & 472.2 & 489.1 & 725.4 & 579.2 & 727.2 & 737.9 & 510.0 & 614.4 & 656.8 \\
\hline Ser & 266.0 & 415.6 & 213.1 & 267.2 & 352.2 & 234.1 & 313.8 & 522.7 & 232.9 & 295.8 & 448.6 & 214.6 \\
\hline Glu & 358.4 & 575.4 & 526.9 & 381.9 & 497.4 & 391.4 & 434.4 & 707.2 & 407.8 & 377.1 & 588.3 & 400.9 \\
\hline Gly & 85.7 & 398.0 & 65.7 & 88.5 & 327.3 & 72.0 & 103.9 & 476.4 & 81.1 & 84.6 & 413.9 & 68.1 \\
\hline Ala & 260.7 & 314.0 & 432.6 & 256.8 & 272.2 & 265.6 & 304.2 & 395.3 & 289.0 & 279.6 & 332.8 & 265.1 \\
\hline Cys & 128.9 & 152.6 & 0.0 & 131.1 & 127.9 & 0.0 & 152.7 & 197.6 & 0.0 & 148.4 & 168.8 & 0.0 \\
\hline Val & 331.1 & 390.6 & 469.0 & 298.4 & 304.9 & 429.2 & 387.4 & 455.3 & 450.2 & 294.0 & 376.3 & 395.7 \\
\hline Met & 153.1 & 234.9 & 200.1 & 154.2 & 200.5 & 202.4 & 190.1 & 300.1 & 214.6 & 170.2 & 251.7 & 199.6 \\
\hline lle & 415.3 & 364.3 & 392.3 & 387.6 & 300.7 & 332.0 & 485.4 & 415.4 & 330.6 & 425.7 & 344.8 & 278.6 \\
\hline Leu & 1286.7 & 1399.5 & 1691.0 & 1277.2 & 1316.9 & 1635.7 & 1449.6 & 1623.5 & 1713.2 & 1338.1 & 1418.9 & 1567.3 \\
\hline Tyr & 923.3 & 784.9 & 1237.0 & 940.4 & 654.4 & 1042.4 & 1074.8 & 964.7 & 1095.8 & 1026.6 & 782.7 & 991.1 \\
\hline Phe & 675.8 & 674.3 & 1034.6 & 634.1 & 555.8 & 1027.8 & 730.7 & 825.6 & 1091.6 & 669.4 & 671.9 & 1017.5 \\
\hline Lys & 1895.9 & 1572.8 & 1641.9 & 1908.3 & 1342.9 & 1486.5 & 2116.5 & 1870.9 & 1483.7 & 2034.8 & 1595.3 & 1325.5 \\
\hline His & 185.7 & 216.0 & 157.5 & 181.4 & 177.1 & 142.7 & 220.3 & 268.5 & 147.7 & 197.9 & 223.9 & 133.1 \\
\hline Arg & 529.5 & 561.1 & 704.1 & 502.1 & 374.0 & 653.1 & 611.4 & 579.3 & 665.1 & 549.4 & 500.5 & 594.3 \\
\hline Pro & 73.6 & 54.1 & 29.0 & 66.9 & 41.4 & 26.4 & 78.4 & 62.8 & 25.1 & 74.7 & 52.5 & 24.7 \\
\hline
\end{tabular}

promotion effect. Storcksdieck et al. reported that Asp, Glu, Gly, and Pro in the gel filtration fraction from the pepsin/pancreatin digests of meat protein were responsible for iron binding. Both Asp and Glu are known to form stable iron chelates with a putative tridentate structure (10). Many investigators have pointed out that Cys could exert a reducing effect on the ferric form $\left(\mathrm{Fe}^{3+}\right)$, keeping iron in its ferrous form $\left(\mathrm{Fe}^{2+}\right)$, which is better for absorption (6). His may bind iron through imidazole nitrogen (28). Argyri et al. reported the hexapeptide PGPIPN (Pro-Gly-Pro-Ile-Pro-Asp) rich in Pro exerted an enhancing effect on iron uptake in Caco-2 cells in a dose-reponsive manner (29). It has been suggested that Pro induces structural bonds in proteins (30) and thus might aid peptides in assuming a conformation that favors stable iron binding. Additionally, the stability of these complexes might be further enhanced by the resistance of Pro-rich peptides to digestion due to steric hindrance (10). Only at the brush border are Pro bonds cleaved by dipeptidyl peptidase IV and related enzymes (31). Although Neutrase-treated hydrolysates exhibited the most promoting effect on iron absorption, they did not have a high content of the amino acids known to enhance iron bioavailability. We hypothesized that relatively low MW $(<10 \mathrm{kDa})$ peptides instead of amino acids served as the major facilitators of iron bioavailability.

\section{ABBREVIATIONS USED}

Ala, alanine; Arg, argnine; Asp, aspartic acid; Cys, cystine; Glu, glutamic acid; Gly, glycine; His, histidine; Ile, isoleucine; Leu, leucine; Lys, lysine; Met, methionine; Phe, phenylalanine; Pro, proline; Ser, serine; Thr, threonine; Trp, tryptophan; Tyr, tyrosine; BSA, bovine serum albumin; IgG, immunoglobulin $\mathrm{G}$; $\beta$-Lg, $\beta$-lactoglobulin; $\alpha$-La, $\alpha$-lactalbumin.

\section{ACKNOWLEDGMENT}

We gratefully acknowledge the assistance of Lin Li and Liu Xiaoli for mineral and amino acid analyses.

\section{LITERATURE CITED}

(1) Liang, J.; Han, B.; Nout, M. J. R.; Hamer, R. J. Effect of soaking and phytase treatment on phytic acid, calcium, iron and zinc in rice fractions. Food Chem. 2009, 115, 789-794.

(2) Liang, J.; Han, B.; Nout, M. J. R.; Hamer, R. J. Effects of soaking, germination and fermentation on phytic acid, total and in vitro soluble zinc in brown rice. Food Chem. 2008, 110, 821-828.
(3) $\mathrm{Yu}$, B. Attention on iron fortification - the application of NaFeEDTA in food. Sci. Technol. Food Ind. 2007, 4, 34-35 (in Chinese).

(4) Ishikawa, S. I.; Tamaki, S.; Arihara, K.; Itoh, M. Egg yolk protein and egg yolk phosvitin inhibit calcium, magnesium, and iron absorptions in rats. J. Food Sci. 2007, 72, S412-S419.

(5) Etcheverry, P.; Miller, D. D.; Glahn, R. P. A low-molecular-weight factor in human milk whey promotes iron uptake by Caco-2 cells. J. Nutr. 2004, 134, 93-98.

(6) Lynch, S. R. Interaction of iron with other nutrients. Nutr. Rev. 1997, 55, 102-110.

(7) De Souza Nogueira, C.; Colli, C.; Maria Silverio Amancio, O. Infant formula iron dialysability related to other nutrients. Food Chem. 2005, 90, 779-783.

(8) Sugiarto, M.; Ye, A.; Singh, H. Characterisation of binding of iron to sodium caseinate and whey protein isolate. Food Chem. 2009, 114, $1007-1013$.

(9) Remondetto, G. E.; Beyssac, E.; Subirade, M. Iron availability from whey protein hydrogels: an in vitro study. J. Agric. Food Chem. 2004, $52,8137-8143$.

(10) Storcksdieck genannt Bonsmann, S.; Hurrell, R. F. Iron-binding properties, amino acid composition, and structure of muscle tissue peptides from in vitro digestion of different meat sources. J. Food Sci. 2007, 72, S019-S029.

(11) Kim, M.; Lee, D. T.; Lee, Y. S. Iron absorption and intestinal solubility in rats are influenced by dietary proteins. Nutr. Res. (N.Y.) 1995, 15, 1705-1716.

(12) Mulvihill, B.; Morrissey, P. A. Influence of the sulphydryl content of animal proteins on in vitro bioavailability of non-haem iron. Food Chem. 1998, 61, 1-7.

(13) Kim, S. B.; Seo, I. S.; Khan, M. A.; Ki, K. S.; Nam, M. S.; Kim, H. S. Separation of iron-binding protein from whey through enzymatic hydrolysis. Int. Dairy J. 2007, 17, 625-631.

(14) Lee, S. H.; Song, K. B. Purification of an iron-binding nona-peptide from hydrolysates of porcine blood plasma protein. Process Biochem. 2009, 44, 378-381.

(15) Kim, S. B.; Seo, I. S.; Khan, M. A.; Ki, K. S.; Lee, W. S.; Lee, H. J.; Shin, H. S.; Kim, H. S. Enzymatic hydrolysis of heated whey: Ironbinding ability of peptides and antigenic protein fractions. J. Dairy Sci. 2007, 90, 4033-4042.

(16) Smithers, G. W. Whey and whey proteins - from 'gutter-to-gold'. Int. Dairy J. 2008, 18, 695-704.

(17) Adler-Nissen, J. Determination of the degree of hydrolysis of food protein hydrolysates by trinitrobenzenesulfonic acid. J. Agric. Food Chem. 1979, 27, 1256-1262.

(18) Kiers, J. L.; Van Laeken, A.; Rombouts, F. M.; Nout, M. In vitro digestibility of Bacillus fermented soya bean. Int. J. Food Microbiol. 2000, 60, 163-169. 
(19) Glahn, R. P.; Lee, O. A.; Yeung, A.; Goldman, M. I.; Miller, D. D. Caco-2 cell ferritin formation predicts nonradiolabeled food iron availability in an in vitro digestion/Caco-2 cell culture model. J. Nutr. 1998, 128, 1555-1561.

(20) Glahn, R. P.; Gangloff, M. B.; van Campen, D. R.; Miller, D. D.; Wien, E. M.; Norvell, W. A. Bathophenanthrolene disulfonic acid and sodium dithionite effectively remove surface-bound iron from Caco-2 cell monolayers. J. Nutr. 1995, 125, 1833-1840.

(21) Gargari, B. P.; Razavieh, S. V.; Mahboob, S.; Niknafs, B.; Kooshavar, H. Effect of retinol on iron bioavailability from Iranian bread in a Caco-2 cell culture model. Nutrition 2006, 22, 638-644.

(22) Schagger, H.; Von Jagow, G. Tricine-sodium dodecyl sulfatepolyacrylamide gel electrophoresis for the separation of proteins in the range from 1 to $100 \mathrm{kDa}$. Anal. Biochem. 1987, 166, 368-379.

(23) Kim, M.; Lee, D. T.; Lee, Y. S. Iron absorption and intestinal solubility in rats are influenced by dietary proteins. Nutr. Res. (N.Y.) 1995, 15, 1705-1716.

(24) Hurrell, R. F.; Lynch, S. R.; Trinidad, T. P.; Dassenko, S. A.; Cook, J. D. Iron absorption in humans as influenced by bovine milk proteins. Am. J. Clin. Nutr. 1989, 49, 546-552.

(25) Perales, S.; Barber, R.; Lagarda, M. J.; Farr, R. Availability of iron from milk-based formulas and fruit juices containing milk and cereals estimated by in vitro methods (solubility, dialysability) and uptake and transport by Caco-2 cells. Food Chem. 2007, 102, 12961303.
(26) Kim, S. B.; Seo, I. S.; Khan, M. A.; Ki, K. S.; Nam, M. S.; Kim, H. S. Separation of iron-binding protein from whey through enzymatic hydrolysis. Int. Dairy J. 2007, 17, 625-631.

(27) Sukan, G.; Andrews, A. T. Application to the plastein reaction to casein and skim-milk powder. J. Dairy Res 1982, 49, 265-78.

(28) Chaud, M. V.; Izumi, C.; Nahaal, Z.; Shuhama, T.; Bianchi, M.; Freitas, O. Iron derivatives from casein hydrolysates as a potential source in the treatment of iron deficiency. J. Agric. Food Chem. 2002, 50, 871-877.

(29) Argyri, K.; Miller, D. D.; Glahn, R. P.; Zhu, L.; Kapsokefalou, M. Peptides isolated from in vitro digests of milk enhance iron uptake by Caco-2 cells. J. Agric. Food Chem. 2007, 55, 10221-10225.

(30) Yang, W. Z.; Ko, T. P.; Corselli, L.; Johnson, R. C.; Yuan, H. S. Conversion of $\beta$-strand to an $\alpha$-helix induced by a single-site mutation observed in the crystal structure of Fis mutant Pro ${ }^{26}$ Ala. Protein Sci. 1998, 7, 1875-1883.

(31) Yaron, A.; Naider, F.; Scharpe, S. Proline-dependent structural and biological properties of peptides and proteins. Crit. Rev. Biochem. Mol. Biol. 1993, 28, 31-81.

Received for review January 6, 2010. Revised manuscript received March 1, 2010. Accepted March 1, 2010. Financial support was provided by the project of DRIs of Iron and Calcium for Chinese People (No. 2008BAI58B02), from the Ministry of Science and Technology, People's Republic of China. 